\title{
O PROBLEMACH Z TEUMACZENIAMI DWUJĘZYCZNEJ SPUŚCIZNY LUDWIKA FLECKA NA PRZYKŁADZIE POJĘCIA „LEGITYMACJI”1
}

Paweł Jarnicki

Projekt Nauka. Fundacja na rzecz Promocji Nauki Polskiej

Ludwik Fleck urodził się w 1896 roku we Lwowie w zlaicyzowanej rodzinie żydowskiej. Był polskim mikrobiologiem zainteresowanym również filozofia nauki. Szczytowy okres jego teoretycznej twórczości przypadł na lata 1934-1936. Zmarł w 1961 roku w Izraelu. Jego prace filozoficzne, choć recenzowane jeszcze za życia, doczekały się należnej recepcji dopiero po tym, jak Thomas Kuhn wspomniał jego książkę jako źródło inspiracji w swojej słynnej, wydanej w 1962 roku Strukturze rewolucji nankowych ${ }^{2}$.

Od tego czasu minęło przeszło pięćdziesiąt lat, teksty Flecka funkcjonuja już przynajmniej w 10 językach, bibliografie recepcji teorii polskiego mikrobiologa w językach polskim, niemieckim i angielskim liczą po dwieście, trzysta pozycji. W 2005 roku w Zurychu przy Collegium Helveticum przy Politechnice Zuryskiej (ETHZ) powstały Centrum Ludwika Flecka oraz Archiwum Ludwika Flecka. Jednak pomimo rosnącej popularności Flecka nikt nie zadawał sobie dotychczas pytań związanych z tym, jakie problemy wiążą się z dwujęzycznością jego spuścizny. Urodzony w zaborze austriackim władał biegle językami polskim i niemieckim, i w obu pisał.

\footnotetext{
Praca powstała w ramach projektu pt. Filologiczna analiza filozoficznych driet Ludwika Flecka oraz ich ttumaczeńn w jezykach: polskim, niemieckim $i$ angielskim finansowanego ze środków Narodowego Centrum Nauki przyznanych na podstawie decyzji numer DEC-2012/06/M/HS2/00313. Krótsza wersja tego artykułu ukazała się po angielsku (Jarnicki 2015: 167-184).

2 Więcej o życiu i filozofii Flecka w encyklopedycznym artykule (Sady 2012) oraz w szkicu biograficznym (Leszczyńska 2007); recepcji jego teorii poświęcony jest numer specjalny czasopisma „Studia Philosophica Wratislaviensia” (Jarnicki 2011).
} 
Nie był wyjątkiem, przecież wielu polskich intelektualistów tamtego czasu tworzyło jednocześnie w dwu językach. Nie udało mi się jednak znaleźć translatologicznej analizy podobnego przypadku.

Mamy dziś w związku z teorią Flecka do czynienia z sytuacją szczególną. Staje się ona coraz bardziej popularna nie tylko w Polsce i w Niemczech, ale - za sprawą angielskich tłumaczeń - również na całym świecie: Fleck staje się „klasykiem”. W tym samym czasie większość badaczy nawet w Polsce i w Niemczech czyta Flecka - istnieja już przecież pisma zebrane - w połowie w przekładach. Przekłady te okazują się tymczasem niespójne z oryginalnymi tekstami Flecka. Tłumaczono je bowiem jak zwykłe teksty, nie uwzględniając dwujęzyczności autora, tworzącego teorię naukową jednocześnie w dwu językach.

\section{/// Dwujęzyczny Fleck i jedna teoria stylów i kolektywów myślowych}

Znany jest przypadek Hannah Arendt (1906-1975), która do czasu emigracji do Stanów Zjednoczonych pisała po niemiecku, potem zaś po angielsku. Jednak analizy jej twórczości dokonane przez osoby, dla których oba te języki są językami „pierwszymi”, pokazują, że nawet mieszkając od wielu lat w USA, Arendt wciąż myślała po niemiecku. Wnikliwa analiza jej dzieł napisanych oryginalnie po angielsku pokazuje, że pewne ich fragmenty są niejasne, podczas gdy ich niemieckie tłumaczenia wyrażają myśli bardzo klarownie (Brauer 2007). Rodzi to zasadne pytanie o to, po której stronie jest oryginał, po której zaś tłumaczenie; wynika natomiast $\mathrm{z}$ faktu, że angielski nie był dla Arendt językiem „pierwszym” (nie nauczyła się go jako dziecko). Takich watpliwości nie mamy w przypadku Flecka, był on bowiem w przeciwieństwie do Arendt dwujęzyczny.

Kolejnym znanym przypadkiem jest twórczość Samuela Becketta (1906-1989), który sam odpowiadał za tłumaczenia własnych dzieł literackich z języka angielskiego na francuski i francuskiego na angielski. Zważywszy na dwujęzyczność Becketta, mamy tu w pewnym sensie do czynienia $z$ dwoma oryginałami tego samego dzieła - sytuacja dla współczesnego humanisty niewygodna (czyżby istniało jednak dzieło poza tekstem?), ale już przez badaczy opisana (Friedman i in. 1987). Czym przypadek Becketta różni się od przypadku Flecka? Pierwsza różnica polega na tym, że Fleck tworzył teorię naukowa, a nie literaturę, co wiąże się z odmiennymi problemami translatorskimi. Druga różnica polega na tym, że Fleck formułował 
oryginalne teksty w języku polskim i w języku niemieckim, nie dokonywał autoprzekładu (self-translation), tak jak - na różne sposoby - robili to Arendt i Beckett. W przypadku Flecka nie mamy więc do czynienia z dwoma oryginałami jednego dzieła, ale nikt nie podaje w watpliwość faktu, że sformułowana przez niego teoria stylów i kolektywów myślowych i Theorie der Denkstile und Denkekollektive to jedna i ta sama teoria. Podsumowując: dwujęzyczny Ludwik Fleck sformułował jedną teorię stylów i kolektywów myślowych jednocześnie w dwu językach, polskim i niemieckim.

Wszystkie ważniejsze teksty teoretyczne Flecka zostały (po jego śmierci) przełożone z języka polskiego na niemiecki i niemieckiego na polski, większość też została przetłumaczona na język angielski³. Nie można negować zasług dotychczasowych tłumaczy, ich wkład w popularyzację myśli polskiego mikrobiologa jest nieoceniony, niemniej spuścizna Flecka w wymienionych językach pozostaje niespójna. Dowodem jest choćby to, że zbiorowe wydania jego pism, które ukazały się w Polsce (Fleck 2006, 2007) i w Niemczech (Fleck 1980, 1983b, 2011) są pozbawione indeksów pojęć - podstawowego przecież narzędzia badacza. Wyjaśnienie, że chodzi o niedbałość redaktorów, jest (jakkolwiek prawdopodobne) niepełne, bo nawet jeśli chcielibyśmy taki indeks opracować, to natknęlibyśmy się na pewne pojęcia, które w oryginalnym tekście i w tłumaczeniu są oddawane za pomocą odmiennych wyrażeń (kilka przykładów znajduje się w dalszej części tekstu). Tym samym w opracowanym na podstawie oryginalnych tekstów i aktualnych tłumaczeń indeksie znalazłyby się dwa wyrażenia na określenie tego samego pojęcia. Tłumacze na języki polski i niemiecki nie dostrzegli bowiem równoważności niektórych wyrażeń, tak samo zreszta jak tłumacze na język angielski nie rozpoznali równoważności niektórych wyrażeń polskich i niemieckich. O jakiej „równoważności” możemy tu jednak mówić? Zdawałoby się, że pewna równoważność jest oczywista: tak jak Beckett stworzył jedno dzieło, tak Fleck sformułował jedną teorię. Ale przecież teoria musi być sformułowana w jakimś języku, tymczasem teoria Flecka jest sformułowana w dwu językach, z których oba sa językami oryginału, a w odniesieniu do części wyrażeń często nie może być mowy o równoważności na poziomie znaczeń słownikowych. Dlatego proponuję założyć istnienie równoważności na poziomie pojęć. Takie założenie po-

\footnotetext{
3 Wspomniany w pierwszym przypisie projekt dotyczy tekstów Flecka w trzech językach: polskim, niemieckim i angielskim. Poza tymi językami istnieją też tłumaczenia niektórych tekstów Flecka na inne języki: włoski, francuski, hiszpański, rosyjski, szwedzki, brazylijski portugalski.
} 
zwala uznać niektóre wyrażenia, pomimo oczywistych różnic leksykalnych, np. Denkverkehri „krążenie myśli”, za wyrażenia tego samego pojęcia".

Tłumaczenie Flecka jest zadaniem niełatwym, nie tylko ze względu na austriacki dialekt polskich Lwowiaków czy trudną tematykę zagadnień immunologicznych (kiła, reakcja Wassermanna, antygen itd.), z analizy których Fleck wyprowadził swoją teorię. Największe wyzwanie stanowi to, że tłumacząc Flecka na język polski lub niemiecki, tłumaczymy paradoksalnie z języka oryginału na język oryginału. Ta subtelność, zrozumiała jeszcze dla filologów, spotyka się często ze strony niefilologów z zarzutem przesadnej drobiazgowości - to dzielenie włosa na czworo, przykładanie zbyt dużej wagi do kwestii drugo- lub trzeciorzędnych. Mam na te zarzuty dwie odpowiedzi.

Pierwsza - tłumaczenia trzeba uzgodnić z oryginałami, żeby uniknąć sytuacji, w której w wydaniu krytycznym zebranych pism filozoficznych w indeksie pojęć znajdą się dwa wyrażenia tego samego pojęcia - może to bowiem wypaczać recepcję teorii Flecka. Może ktoś na przykład zaczać rozważać, czym się różni u Flecka „legitymacja” od „uzasadnienia”, „uprawomocnienia” bądź „usprawiedliwienia”. Fleck natomiast w swych polskich tekstach używał tylko pierwszego z tych wyrażeń, pozostałe okazują się inwencją tłumaczy (choć pod względem znaczeń słownikowych ich decyzje są często poprawne).

Druga - kilka lat temu napisałem tekst o roli metafor w teorii Flecka (Jarnicki 2008). W skrócie: w tekście tym pokazywałem, jak Fleck używa nowych metafor, by zmienić znaczenie tradycyjnych pojęć filozoficzno-naukowych (obserwacja, odkrycie, fakt naukowy itd.). Do konceptualizacji zastanych pojęć abstrakcyjnych (domen docelowych) używa nowych metafor (rzutowań z nowych domen źródłowych). W konsekwencji pojęcia te stają się wewnętrznie sprzeczne, co ma doprowadzić do przyjęcia nowej, proponowanej przez Flecka, bardziej specjalistycznej terminologii, służącej do opisu poznawania, również naukowego. Chcąc napisać anglojęzyczną wersję tego artykułu, natknąłem się na niemożliwą do przeskoczenia przeszkodę - tam, gdzie w języku polskim znajdowałem jedne metafory, nie znajdowałem ich w angielskim przekładzie lub znajdowałem inne. Napisanie angielskiego tekstu o metaforach u Flecka będzie możliwe dopiero po uspójnieniu przekładów.

Subtelne różnice w tłumaczeniach mogą ponadto zniekształcać recepcję. Przykładowo do amerykańskiego wydania książki Flecka (Fleck 1979)

\footnotetext{
4 Szczegółowo analizuję ten przypadek (Jarnicki 2016). Korpus analizowanych przeze mnie tekstów stanowią: Fleck 1927, 1929, 1934, 1935a, 1935b, 1935c, 1936, 1938, 1939a, 1939b, 1946, 1947 oraz ich tłumaczenia w języku niemieckim, polskim i angielskim: Fleck 1986d.
} 
Stowo wstęne napisal sam Thomas Kuhn. Zarzuca w nim Fleckowi stosowanie w odniesieniu do kolektywu myślowego określeń „zapożyczonych z dyskursu o jednostkach”: „Czasem [Fleck] pisze o «uporczywości [tenacity] zamkniętych systemów przekonań»” (Kuhn 2011: 84)5. Oryginalne niemieckie sformułowanie to Beharrungstendenz der Meinungssysteme. Wydaje się więc, że podstawą zarzutu Kuhna jest właśnie angielskie tłumaczenie tego pojęcia, gdyż o ile angielskie tenacity odnosi się przede wszystkim do „uporu”, „wytrwałości” czy „nieustępliwości” przypisywanych jednostce, o tyle niemieckie Beharrungstendenz już się do tego nie ogranicza i może mieć też znaczenie bliższe „bezwładności” w sensie fizycznym.

Tłumaczenie Flecka to zatem wyzwanie, ale i okazja, by lepiej zrozumieć jego myśl. Możemy podzielić stosowane przez niego wyrażenia na dwie grupy:

1. Wyrażenia konstytutywne dla jego teorii. Tu będa się mieściły przede wszystkim stworzone przez niego pojęcia w rodzaju ,stylu myślowego" oraz pojęcia zaczerpnięte np. z filozofii nauki, ale takie, którym Fleck przypisał własne - odmienne od obowiązujących - znaczenia (tak zmienił np. pojęcie „odkrycia” czy „prawdy”).

2. Wyrażenia przygodne dla jego teorii. Tu będą się mieściły wszystkie inne wyrażenia, których znaczenia Fleck nie zmieniał, standardowe użycia języka, ale też np. terminy medyczne.

Te drugie wydają się najprostsze do tłumaczenia, niemniej wymagaja porównania z częścia jego spuścizny wyrażoną w drugim języku. Przykładowo w oryginalnych polskich tekstach Fleck nie posługiwał się - używanym współcześnie - wyrażeniem „przeciwciało”, ale starszym: „niwecznik", tymczasem polscy tłumacze niemieckie Antikörper tłumaczyli jako „przeciwciało”, przez co mamy w tekstach Flecka i „przeciwciała”, i „niweczniki”, które oznaczają to samo pojęcie. Drugi, podobny przykład dotyczy „malarii”, której nie ma w oryginalnych polskich tekstach, Fleck używał bowiem starszego wyrażenia: „zimnica”.

Dużo ważniejsze są jednak wyrażenia, które uznamy za konstytutywne. Możemy tu mówić o dwu możliwych sytuacjach:

1. Istnieją wyrażenia równoważne, które Fleck stosował w obu językach, np. Deknverkehr/,krążenie myśli”; Legitimażion/,legitymacja”.

2. Istnieja wyrażenia, które Fleck stosował wyłącznie w jednym języku, np. passiv/aktiv Koppelung; Beharrungstendenz der Meinungsysteme.

O ile druga sytuacja jest bliższa zwykłej sytuacji tłumacza, o tyle pierwsza jest szczególna dla spuścizny Flecka. Dotychczasowi tłumacze Flecka

\footnotetext{
„Sometimes he writes of the «tenacity of closed systems of opinion»” (Kuhn 1979: X).
} 
na polski - w przeciwieństwie do tłumaczy niemieckich - nie rozpoznali np. wyrażeń Legitimazion i „legitymacja” jako równoważnych i ma to znaczące konsekwencje dla rozumienia jego teorii w języku polskim.

\section{/// Przypadek „legitymacji”}

Pojęcie „legitymacji” jest bez wątpienia istotne dla pełnego zrozumienia teorii Flecka. Dziś „legitymacja” kojarzy się przede wszystkim ze szkolnym dokumentem, u Flecka jednak ma ona jeszcze inne, mniej dziś rozpoznawalne w języku potocznym znaczenie związane ze sfera prawa. Zanim jednak przyjrzymy się kilku cytatom, by to wyrażenie mogło stać się zrozumiałe, trochę statystyki.

W oryginalnych tekstach polskich można znaleźć 15 pokrewnych wyrażeń „legitymacji” w różnych formach: czasownikowej i imiesłowowej $\mathrm{w}$ aspekcie dokonanym (wylegitymować - 1 , wylegitymowany - 2) i niedokonanym (legitymowaí - 1), w formie rzeczownika odczasownikowego (legitymowanie - 4), w formie rzeczownika (legitymacja - 6) i w formie przymiotnika (legitymacyjny - 1).

Wyrażenia te są tłumaczone na język niemiecki za pomocą: legitimieren (2), Legitimierung (10), legitimiert (2), Legitimieren (1). Tłumacze na niemiecki w tym wypadku podejmowali konsekwentne decyzje zgodne $\mathrm{z}$ wyrażeniami używanymi przez Flecka po niemiecku. W języku angielskim natomiast sytuacja jest już bardziej zróżnicowana, użyte wyrażenia pochodzą od trzech czasowników: identify (1), identified (1), identification (1), justify (1), legitimization (8), legitimiæing (2), legitimized (1). Nie twierdzę bynajmniej, że należy ustanowić absolutne zasady odnośnie do tłumaczenia jednego wyrażenia polskiego za pomoca jednego wyrażenia angielskiego, zależy to oczywiście od kontekstu.

W oryginalnych tekstach niemieckich znaleźć można 21 pokrewnych wyrażeń w formie czasownikowej i imiesłowowej (legitimieren - 5, legitimiert - 3, nicht zu legitimierend - 2), w formie rzeczownika odczasownikowego (Legitimieren - 1), w formie rzeczownika (Legitimierung - 7) i w formie przymiotnika (legitimierbar - 3).

Wyrażenia powyższe są tłumaczone na język polski za pomocą wyrażeń pochodzących od 8 różnych rdzeni: oparty (1), niepotwierdzany (1), potwierdzony (2), potwierdzać (1), potwierdzenie (2), udowodnić (1), ugruntowanie (1), uprawomocniać (2), uprawomocnienie (4), usprawiedliwiać (1), usprawiedliwiony (1), uzasadnić (1), urasadnienie (1), urasadniony (1), wyttumaczenia, nie do (1). W angielskich tłumaczeniach znajdziemy natomiast wyrażenia pochodzące od 4 rdzeni: 
confirm (1), confirmation (1), confirmed (1), confirmed, that cannot be (1), justification (1), justified (1), justified, that cannot be (1), justify (2), legitimacy (1), legitimation (1), legitimization (3), legitimize (4), legitimized (2), substantiate (1).

Opracowana na tej podstawie lista wyrażeń synonimicznych wygląda następująco (poprzestaję na formach czasownika):

\begin{tabular}{|c|c|c|}
\hline w języki polskim & w języku niemieckim & w języku angielskim \\
\hline legitymować & \multirow[t]{9}{*}{ legitimieren } & \multirow[t]{5}{*}{ legitimize } \\
\hline uzasadniać & & \\
\hline uprawomocniać & & \\
\hline usprawiedliwiać & & \\
\hline potwierdzać & & \\
\hline udowadniać & & justify \\
\hline tłumaczyć & & confirm \\
\hline ugruntowywać & & identify \\
\hline opierać & & substantiate \\
\hline
\end{tabular}

Spośród polskich wyrażeń najważniejszymi synonimami „legitymowania” w znaczeniu zaczerpniętym ze sfery prawa wydają się wyrazy „,uzasadniać” i „uprawomocniać”. „Mieć legitymację” znaczy mniej więcej „mieć prawo”, „mieć uzasadnienie”, „być uprawomocnionym”. Przegląd korpusu w poszukiwaniu tych wyrażeń w oryginalnych polskich tekstach Flecka pokazuje jednak, że Fleck jeden raz pisze o ,teoretycznie uzasadnionym porządku” i drugi raz używa wyrażenia pochodnego w zwykłym sensie („,nie wiem, czy uzasadnione jest twierdzenie”), ,uprawomocnienia” ani „usprawiedliwienia” zaś nie używa ani razu. Pozostałe wyrażenia z powyższej tabeli wydają się bardziej przypadkowymi decyzjami tłumaczy. Fleck używa ich w polskich oryginałach, ale jak się zdaje, w innym zupełnie znaczeniu i w innych kontekstach; rozstrzygnie to dalsza analiza konkretnych fragmentów.

Czy możemy wyróżnić jakieś stałe konteksty wyrażeń pokrewnych „legitymacji”’? Czy da się znaleźć fragmenty w tekstach polskich i niemieckich, w których Fleck pisze mniej więcej to samo? Co w ogóle Fleck rozumie pod tym pojęciem? Czy Fleck używał tego wyrażenia w znaczeniu, które dziś mu nadajemy, mówiąc o „kontekście uzasadniania”? Przyjrzyj-

6 Więcej o różnicy między „kontekstem odkrycia” a „kontekstem uzasadniania” w piątej części artykułu encyklopedycznego (Schickore 2014). 
my się kilku przykładom z języka polskiego i niemieckiego. W poniższych przykładach tekst oryginalny znajduje się zawsze w lewej kolumnie.

Formułować myśl można, zdaniem Flecka, gdy się ma na celu jej „popularyzację", czyli gdy się mówi do tych, którzy się na tym, o czym mówimy, za bardzo nie znaja. Można też mówić do równych sobie pod względem wiedzy, wtedy mamy do czynienia $z$, informacją”. „Legitymacja” jest trzecim członem tego szeregu. Jeśli za wspólny element tych członów można przyjąc adresata wypowiedzi, to w przypadku „legitymacji” należałoby powiedzieć, że adresatem jest sam kolektyw myślowy. Wspólnego mianownika można dopatrywać się też w celu tych wypowiedzi, szereg należałoby wtedy sparafrazować następująco: rozpowszechnianie, powtarzanie, uzasadnianie. Tak pierwsza forma, jak i trzecia wiążą się z przekształceniami, w pierwszej dopasowujemy swoja myśl do zakładanego poziomu wiedzy naszego adresata, w trzeciej dopasowujemy ją do aktualnego stanu wiedzy specjalistycznej.

Jeśli myśl jakąś treści poznawczej formułuję dla członków własnego kolektywu, może to mieć na celu: 1) popularyzacje jej, jeśli idzie o laików z tego kolektywu, 2) informacje o niej, jeśli idzie równorzędnych fachowców lub wreszcie

3) о legitymacje jej w ramach stylowego systemu ideowego, tj. o sformułowanie jej oficjalne, ważne dla kolektywu jako takiego.

Każdy zgodzi się na to, że zarówno popularyzacja jak i legitymacja powoduja przeinaczenie socjalnej wartości wypowiedzi (Fleck 1936: 10).
Wenn ich einen Gedanken von Erkenntnisinhalt für Mitglieder des eigenen Kollektivs formuliere, kann dies bezwecken: (1) seine Popularisierung, wenn es um Laien aus diesem Kollektiv geht, (2) die Information über ihn, wenn es um gleichwertige Fachleute geht, oder schließlich (3) seine Legitimierung im Rahmen des stilgemäßen Ideensystems, d. h. seine offizielle Formulierung, gültig für das Kollektiv als solches.

Jedermann wird der Meinung zustimmen, daß Popularisierung gleichermaßen wie Legitimierung die Veränderung des sozialen Werts einer Aussage verursachen (Fleck 1983a: 92-93).
If I formulate a certain idea of epistemological content for the purpose of my own collective, this can aim at: (1) its popularization, as far as laymen of that collective are concerned, (2) information regarding it, as far as the equivalent specialists are concerned, and, finally (3) its legitimization within the framework of the style-system of ideas, i.e. its official formulation, valid for the collective as such.

Everybody will agree that both popularization and legitimization bring about a change of the social value of the utterance (Fleck 1986d: 86). 
Poniższe zdania pokazują, że Fleck przez „legitymację” rozumiał mniej więcej to, co Hans Reichenbach nazwał kontekstem uzasadniania. W uproszczeniu, nie liczy się to, w jaki sposób do odkrycia doszło (,związki psychologiczne i historyczne"), liczy się to, jak to jest uzasadniane logicznie („,schematy całego systemu”).

Legitymacja wypowiedzi wyodrębnia ją od jej genetycznych związków psychologicznych i historycznych, a przystosowuje do schematów całego systemu (Fleck 1936: 10).

Potem, krążąc już wśród tłumu interferuje myśl nowa z tegoż zapasem myślowym i dostosowuje się do swoistego stylu myślowego zespołu. Każda nowa myśl podlega legitymowaniu według reguł tego stylu, więc ulega przekształceniu legitymacyjnemu (Fleck 1936: 11).

\section{Die Legitimierung} einer Aussage löst sie aus ihren genetischen, psychologischen und geschichtlichen Zusammenhängen heraus und paßt sie den Schemata des Gesamtsystems an (Fleck 1983a: 93).

\section{Danach, innerhalb der} Masse kreisend, interferiert der neue Gedanke mit deren Gedankenvorrat und paßt sich dem spezifischen Denkstil der Gemeinschaft an. Jeder neue Gedanke unterliegt der Legitimierung nach den Regeln dieses Stils, wird also einer Umgestaltung durch Legitimierung unterworfen (Fleck 1983a: 94).

\section{The legitimization of the statement isolates it from its genetic psy- chological and historical relations, and adapts it to the schemas of the entire system (Fleck 1986d: 86).}

$$
\begin{aligned}
& \text { Next, now circulating } \\
& \text { within the crowd, the } \\
& \text { new thought interferes } \\
& \text { with the mental store } \\
& \text { and adjusts itself to } \\
& \text { the specific style of the } \\
& \text { thoughtcollective. Each } \\
& \text { new thought undergoes } \\
& \text { a process of legitimiza- } \\
& \text { tion according to the } \\
& \text { rules of this style, thus } \\
& \text { undergoing a legitimi- } \\
& \text { zation transformation } \\
& \text { (Fleck 1986d: 87). }
\end{aligned}
$$

Można powiedzieć, że przedmiotem teorii Flecka jest nie tyle nauka czy poznanie, ile ich rozwój - rozwój myślenia. Flecka interesuje proces zmiany - poznawanie; we wszystkich powyższych przykładach Fleckowi nie chodzi o ważność „legitymacji”, jej konieczność w nauce jest dla Flecka niekwestionowana - jeśli chcemy, by nasza myśl została przez kolektyw uznana, trzeba ja logicznie uzasadnić. Flecka interesuje to, jakim przekształceniom ulega oryginalna myśl w trakcie wbudowywania jej w istniejącą już wiedzę.

Wydaje się, że to samo ma też Fleck na myśli, gdy pisze o „legitymowaniu danych obserwacyjnych”. „Gdzież jest owa czysta obserwacja bez uprzedzeń?" - pyta Fleck. I odpowiada: 


\begin{tabular}{|c|c|c|}
\hline $\begin{array}{l}\text { Obserwacja „dobra”, } \\
\text { ważna raz na zawsze } \\
\text { i dla wszystkich, nieza }\end{array}$ & $\begin{array}{l}\text { Die „,gute” Beobach- } \\
\text { tung, gültig ein für } \\
\text { allemal und für alle, } \\
\text { unabhängig von der Um- } \\
\text { gebung, ihrer Tradition } \\
\text { und von der Epoche? } \\
\text { Sie gibt es nirgends, } \\
\text { weder in der Geschichte } \\
\text { noch im gegenwärtigen } \\
\text { Moment, unmöglich ist } \\
\text { sie auch als Ideal, an das } \\
\text { man sich durch Analyse } \\
\text { oder Kritik annähern } \\
\text { könnte, weil alles „Le- } \\
\text { gitimieren” von Beob- } \\
\text { achtungsdaten genauso } \\
\text { dem Denkstil unterliegt, } \\
\text { was sich immer in den } \\
\text { letzten Elementen des } \\
\text { logischen Aufbaus einer } \\
\text { Wissenschaft zeigen läßt } \\
\text { (Fleck 1983c: 81). }\end{array}$ & $\begin{array}{l}\text { Now where is this pure } \\
\text { observation without } \\
\text { bias? ... a ,good” obser- } \\
\text { vation, valid once for } \\
\text { all, independent of the } \\
\text { surroundings, their tra- } \\
\text { ditions and epoch? One } \\
\text { does not find it anywhere } \\
\text { in history or today, nor } \\
\text { also is it possible as an } \\
\text { ideal which one would } \\
\text { be able to approach by } \\
\text { analysis or criticism, } \\
\text { since any ,identifica- } \\
\text { tion” of the observation } \\
\text { data is likewise subjected } \\
\text { to the thought-style } \\
\text { which is always likely } \\
\text { to be among the last } \\
\text { elements revealed of the } \\
\text { logical structure of sci- } \\
\text { ence (Fleck 1986c: } 77 \text { ). }\end{array}$ \\
\hline
\end{tabular}

Taka obserwacja nie jest możliwa między innymi dlatego, że wszystkie obserwacje, o których się dowiadujemy, muszą zostać zakomunikowane w odniesieniu do aktualnego stanu wiedzy, a więc do niego dostosowane. Angielscy tłumacze zdecydowali się tu błędnie na wybór wyrazu ,identification", które z uzasadnianiem nie ma nic wspólnego.

W inny sposób, ale wciąż w znaczeniu najbliższym „uzasadnianiu”, używa Fleck czasownika „legitymować” w swoim powojennym artykule napisanym częściowo w formie dialogu Simpliciusa i Simpaticusa. Fleck wkłada w nim w usta przeciwnika swojego alter ego następujące - naiwne - słowa:

Dzisiejsza wspaniała technika i jej dalsze możliwości dostatecznie legitymują naszą naukę (Fleck 1946: 326).
Die heutige hervorragende Technik und ihre weiteren Möglichkeiten legitimieren unsere Wissenschaft zur Genüge (Fleck 1983d: 133).
The contemporary splendid technology and its farther possibilities sufficiently justify our science (Fleck 1986b: 117).

Kolejny cytat $z$ niemieckiego tekstu potwierdza, że Fleck traktował „legitymację” jako jedną z reguł nauki, bez „legitymacji” dana myśl, dane odkrycie nie może stać się częścią wiedzy uznawanej za naukową: 
Wendete jemand ein, der Erkenntnistheorie käme es nicht auf die Untersuchung an, wie ein $\mathrm{Zu}-$ sammenhang entdeckt werde, sondern auf seine wissenschaftliche Legitimierung, auf sachliche Beweise und logische Konstruktionen, so wäre zu antworten: Solches

Legitimieren ist sicherlich sehr wichtig und bis zu den gewöhnlichen Grenzen und mit gewöhnlicher Genauigkeit trifft es auch in unserem Falle zu. Sonst wäre die Syphilislehre kein Wissenschaftsbestandteil (Fleck 1935a: 30).
Tym, którzy uważają, że dla teorii poznania nie jest ważna droga prowadząca do odkrycia jakiegoś związku, ale jego naukowe uprawomocnienie, obiektywne dowody i logiczne konstrukcje, należałoby odpowiedzieć: Tego rodzaju uprawomocnienie jest na pewno bardzo ważne i w określonych granicach oraz z określoną dokładnością odnosi się także do naszej dziedziny. Bez spełnienia tego warunku wiedza o kile nie byłaby cząstką wiedzy naukowej (Fleck 1986a: 50).
For epistemology, it might be objected, it is not important to investigate how a connection was discovered, but only to legitimize it scientifically, prove it objectively, and construct it logically. But this could be countered as follows.

Legitimization is certainly very important in science generally and, within reasonable bounds and precision, to our case as well; otherwise syphilology would not be a branch of science (Fleck 1979: 22).

W tym przypadku wybór polskiej tłumaczki nie wypacza sensu wypowiedzi Flecka, ale nie jest najlepszym z możliwych wyborów, nie chodzi tu bowiem o „nadanie” czy „nabranie mocy prawnej” (a to znaczy „uprawomocnienie”), ale o „uzasadnienie” ewentualnie ,uargumentowanie”. Jednak nie ma powodu, by wprowadzać takie wyrażenia, skoro Fleck używał w swych polskich tekstach „legitymacji”.

W dalszej części książki Fleck pisze:

Folglich sind praktisch überhaupt keine Protokollsätze aufstellbar, die sich auf unmittelbare Beobachtung beziehen würden und aus denen durch logisches Schließen die Ergebnisse folgten. Dergleichen ist nur während nachträglicher Legitimierung eines Wissens möglich, nicht aber während der eigentlichen Erkenntnisarbeit (Fleck 1935a: 96).
W konsekwencji nie można praktycznie sformułować żadnych zdań protokolarnych odnoszących się do bezpośredniej obserwacji, z których na podstawie logicznych założeń wynikałyby wnioski. Jest to jedynie możliwe podczas późniejszego potwierdzenia jakiegoś odkrycia w praktyce, nigdy zaś podczas jego dokonywania (Fleck 1986a: 120).
Consequently it is all but impossible to make any protocol statements [Protokollsätze] based on direct observation and from which the results should follow as logical conclusions. This can be done only during the subsequent confirmation of a finding [eines Wissens] but not while making the effort of acquiring it (Fleck 1979: 89). 
W tym wypadku polskie tłumaczenie, tak zresztą jak i angielskie, znacząco zmienia znaczenie oryginału. Nie chodzi tu bowiem o potwierdzanie, ale o „legitymacje”, o uzasadnianie. Pierwotna obserwacja, jeśli istnieje, to tylko w głowie odkrywcy, który aby ją zakomunikować, musi odnieść się do tego, co już wiadomo. Zdanie to zyskuje Fleckowskie znaczenie dopiero wtedy, gdy za „potwierdzanie w praktyce” podstawimy „legitymowanie”.

Powyższe przykłady pokazują, że Fleck używał wyrazu „legitymacja” i jego pochodnych w znaczeniu najbliższym dzisiejszemu „uzasadnianiu”, jednak ze względu na to, że nie stosował „uzasadniania” w swoich oryginalnych polskich tekstach, w nowych tłumaczeniach z niemieckiego na polski należałoby poprzestać na „legitymacji”.

Die Prinzipien eines fremden Kollektivs empfindet man — wenn man sie überhaupt bemerkt — als willkürlich, ihre eventuelle Legitimierung als petitio principii (Fleck 1935a: 115-116).

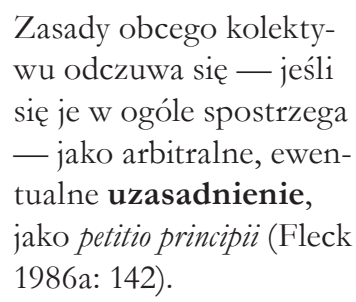
jako petitio principii (Fleck 1986a: 142).

\begin{abstract}
The principles of an alien collective are, if noticed at all, felt to be arbitrary and their possible legitimacy as begging the question (Fleck 1979: 109).
\end{abstract}

\section{/// Podsumowanie}

Ludwik Fleck stworzył teorię stylów i kolektywów myślowych, która stała się rozpoznawalna na całym świecie; teksty, w których tę teorię wyraził, napisał jednocześnie w dwu językach - polskim i niemieckim. Rodzi to specyficzne problemy z tłumaczeniem tych tekstów, bo tłumacz z języka niemieckiego na polski powinien również uwzględniać sformułowania w oryginalnych polskich tekstach i vice versa. Dotychczasowi tłumacze, jeśli uwzględniali ten czynnik, czynili to wyłącznie intuicyjnie, odwołując się w procesie tłumaczenia do swojej znajomości teorii Flecka.

Można proces tłumaczenia porównać w pewnym sensie do Fleckowskiego „krążenia” bądź „wymiany myśli”, które z zasady nie mogą się obyć bez mniejszych bądź większych „przeinaczeń”: „Zasadniczo porozumienie możliwe jest tylko w obrębie zespołu, pomiędzy pokrewnymi zespołami odbywa się ono już z pewnym powikłaniem: międzygrupowa wymiana myśli połączona jest zawsze z mniej lub więcej wybitnym przeinaczeniem jej. Przechodząc z jednej grupy do drugiej, zmieniają słowa swe znaczenie, pojęcia otrzymują inne zabarwienie stylowe, zdania inny sens, poglądy inną

\section{/ 366 STANRZECZY 1[10]/2016}


wartość. Jeśli grupy są bardzo odległe, może wymiana myśli być zupełnie niemożliwa, transformacja myśli polega wówczas na zupełnym zniszczeniu jej" (Fleck 1936: 9).

Najmniejsze modyfikacje spotykają myśl w ramach wewnątrzgrupowej, wewnątrzkolektywnej wymiany myśli. Ideałem dla tłumacza powinna być wspominana wcześniej „informacja” - wypowiedź, która nie zniekształca myśli, jednak możliwa jest ona tylko wewnątrz konkretnej grupy. Można by zadać pytanie, czy dotychczasowi tłumacze należeli do tej samej grupy myślowej co Fleck? Na przykład polska tłumaczka niemieckiej książki Flecka, Maria Tuszkiewicz, była studentką Flecka - mikrobiologiem. Lączył ją więc z Fleckiem styl myślowy mikrobiologów, niemniej książka, którą Maria Tuszkiewicz przetłumaczyła, jest książką filozoficzna, a polska tłumaczka do kolektywu filozofów nie należała. Nie należy traktować tego jako zarzutu, tłumaczenie Flecka jest bowiem zadaniem zawiłym. Jeśliby kontynuować porównanie tłumaczenia do krążenia myśli wewnątrz kolektywu, to wydaje się, że idealnym tłumaczem Flecka byłby ktoś, kto tak jak Fleck należałby do kolektywu mikrobiologów (tych zainteresowanych historią swojej dziedziny) i filozofów, znał język polski i niemiecki na poziomie mowy ojczystej, a jeśli mówimy o tłumaczeniu na jakiś język trzeci - znajomość trzeciego języka na poziomie mowy ojczystej. Do tego należałoby dodać przychylność względem teorii Flecka i jakieś doświadczenie w tłumaczeniu. Dlatego tłumaczenie Flecka jest tak skomplikowane. Uważam, że nie wystarczy tu sformować zespół ludzi, którzy wspólnie spełnia powyższe warunki, trzeba prócz tego użyć „twardszych” narzędzi. Dlatego w ramach projektu filologicznej analizy filozoficznych pism Flecka najważniejszym narzędziem są synoptyczne tabele oraz systematycznie rozwijany i zmieniany trójjęzyczny glosariusz wyrażeń Fleckowskich. Dopiero użycie takich narzędzi pozwoli ograniczyć „przeinaczenia”, którym uległa myśl Flecka w procesie tłumaczenia jego tekstów.

\section{Przykład synoptycznej tabeli z glosariuszem}

W poprzedzających akapitach Fleck pisze o tym, że nie ma takiego wprowadzenia w naukę (dydaktyka), które nie byłoby w jakimś stopniu autorytatywne. Aby stać się członkiem jakiegoś kolektywu, trzeba przejść okres dogmatycznego szkolenia, swoistego formowania, którego nie da się ująć wyłącznie logicznie. Proces ten ma przypominać „święcenia” (w innych miejscach określane też jako „wtajemniczenie”). Fleck zwraca uwagę, że fachowiec, a więc ten, który już jest członkiem kolektywu, nie jest wolny od „przymusu autorytetu” z okresu autorytatywnego nauczania. 
„Der Fachmann ist aber bereits ein speziell geformter Mensch, der seiner traditionellen und kollektiven Bindung nicht mehr entgeht, sonst wäre er kein Fachmann. Logisch nicht legitimierbare Momente sind nicht nur zur Einführung notwendig, sondern auch zur Fortführung eines Wissens, selbst zur Legitimierung eines Wissensgebietes, die doch eine Wissenschaft für sich ist" (Fleck 1935a: 61, Fleck 1980: 74).
„Fachowiec jednak jest specjalnie uformowanym człowiekiem, który już nie może ujść swoim tradycyjnym i kolektywnym związkom, bez których nie byłby fachowcem. Logicznie niepotwierdzone fakty nie sa potrzebne jedynie do wprowadzenia, lecz również do kontynuacji wiedzy, nawet do ugruntowania określonej dziedziny, która współtworzy naukę jako taką" (Fleck 1986a: 84, Fleck 2006: 82).
„But the expert is already a specially molded individual who can no longer escape the bonds of tradition and of the collective; otherwise he would not be an expert. For the introduction, then, factors which are not subject to logical legitimization are also necessary, as well as essential both to the further development of knowledge and to the justification of a branch of knowledge that constitutes a science in itself" (Fleck 1979: 54).

\section{Propozycje zmian w tłumaczeniach}

$\begin{array}{ll}\text { „Der Fachmann ist } & \text { Fachowiec jest jednak już } \\ \text { aber bereits ein speziell } & \begin{array}{l}\text { specjalnie uformowanym } \\ \text { geformter Mensch, der }\end{array} \\ \text { człowiekiem, który już } \\ \text { kollektiven Bindung } & \text { nie ucieknie przed swoimi } \\ \text { nicht mehr entgeht, } & \text { i kolektywem, inaczej } \\ \text { sonst wäre er kein } & \text { nie byłby fachowcem. } \\ \text { Fachmann. Logisch } & \text { Momenty, które nie } \\ \text { nicht legitimierbare } & \text { dają się logicznie } \\ \text { Momente sind nicht } & \text { wylegitymować są } \\ \text { nur zur Einführung } & \text { konieczne nie tylko dla } \\ \text { notwendig, sondern } & \text { wstępu [Einführung], ale } \\ \text { auch zur Fortführung } & \text { i dla postępu [Fortführung] } \\ \text { eines Wissens, selbst zur } & \text { wiedzy, a nawet dla } \\ \text { Legitimierung eines } & \text { legitymacji [danej] } \\ \text { Wissensgebietes, die doch } & \text { dziedziny wiedzy, która } \\ \text { eine Wissenschaft für } & \text { przecież stanowi odrębną } \\ \text { sich ist” (Fleck 1935a: 61, } & \text { naukę. } \\ \text { Fleck 1980: 74). } & \end{array}$

But the specialist is already a specially formed man who will not escape any more from his connections with tradition and collective, otherwise he would not be a specialist. The moments that are impossible to legitimize logically are necessary not only for the prologue [Einfübrung], but also for the progress [Fortfübrung] of knowledge, and even for the legitimation of a [given] field of knowledge, that yet constitutes a science apart. 
Glosariusz do powyższego fragmentu

\begin{tabular}{|l|l|l|}
\hline Bindung & związek & connection \\
\hline Einführung & $\begin{array}{l}\text { wprowadzenie } \\
\text { wstęp }\end{array}$ & $\begin{array}{l}\text { introduction } \\
\text { prologue }\end{array}$ \\
\hline entgehen & uciekać & escape \\
\hline Fachmann & fachowiec & specialist \\
\hline Fortführung & postęp & progress \\
\hline geformt & uformowany & formed \\
\hline kollektiv & kolektywny & collective \\
\hline legitimierbar, nicht & $\begin{array}{l}\text { wylegitymować, nieda- } \\
\text { jacy się }\end{array}$ & impossible to legitimize \\
\hline Legitimierung & legitymacja & legitimation \\
\hline logisch & logicznie & logically \\
\hline Mensch & człowiek & man \\
\hline Moment & moment & moment \\
\hline notwendig & konieczny & necessary \\
\hline speziell & specjalnie & specially \\
\hline traditionell & tradycja, z [tradycyjny] & knowledge \\
\hline Wissen & nauka & field of knowledge \\
\hline Wissenschaft & dziedzina wiedzy & \\
\hline Wissensgebiet & & nalio- \\
\hline
\end{tabular}

Bibliografia:

/// Brauer G.W. 2007. Is There an Educational Problem with Reading Hannah Arendt's The Human Condition in English Only? https://open.library.ubc.ca/ cIRcle/collections/ubctheses/831/items/1.0100589; dostęp: 08.10.2016.

/// Fleck L. 1927. O niektórych swoistych cechach myślenia lekarskiego, „Archiwum Historii i Filozofii Medycyny oraz Historii Nauk Przyrodniczych", t. 6 , nr 1, s. 55-64. 
/// Fleck L. 1929. Zur Krise der „Wirklichkeit”, „Die Naturwissenschaften”, t. 23 , s. $425-430$.

/// Fleck L. 1934. Jak powstał odczyn Bordet-Wassermanna i jake w ogóle powstaje odkrycie naukowe?, „Polska Gazeta Lekarska”, nr 10, s. 181-182, nr 11, s. 202-205.

/// Fleck L. 1935a. Entstehung und Entwicklung einer wissenschaftlichen Tatsache. Einführung in die Lehre vom Denkstil und Denkkollektiv, Benno Schwabe \& Co. /// Fleck L. 1935b. O obserwacji naukowej i postræeganiu w ogóle, „Przegląd Filozoficzny", t. 38, nr 1, s. 57-76.

/// Fleck L. 1935c. Zur Frage der Grundlagen der mediæinischen Erkenntnis, „Klinische Wochenschrift”, t. 14, nr 35, s. 1255-1259.

/// Fleck L. 1936. Zagadnienie teorii poznawania, „Przegląd Filozoficzny”, t. 39, nr 3, s. 3-37.

/// Fleck L. 1938. W sprawie artykutu p. Izydory Dambskiej w „Przegladzie Filozoficznym”, „Przegląd Filozoficzny”, t. 41, nr 2, s. 192-195.

/// Fleck L. 1939a. Nauka a środowisko, „Przegląd Współczesny”, t. 18, 8-9, s. $149-156$.

/// Fleck L. 1939b. Odpowied乏́, na unagi Tadeusza Bilikiewicza, „Przegląd Współczesny”, t. 18, 8-9, s. 168-174.

/// Fleck L. 1946. Problemy naukoznawstwa, „Życie Nauki. Miesięcznik Naukoznawczy", t. 1, nr 5, s. 322-336.

/// Fleck L. 1947. Patrzéc, widzieé, wiedzieé, „Problemy”, t. 3, nr 2, s. 74-84.

/// Fleck L. 1979. Genesis and Development of a Scientific Fact, tłum. F. Bradley, T.J. Trenn, University of Chicago Press.

/// Fleck L. 1980. Entstebung und Entwicklung einer wissenschaftlichen Tatsache. Einführung in die Lehre vom Denkstil und Denkkollektiv, Suhrkamp.

/// Fleck L. 1983a. Das Problem einer Theorie des Erkennens, tłum. B. Wolniewicz, T. Schnelle, [w:] tegoż, Erfahrung und Tatsache: Gesammelte Aufsätre, red. T. Schnelle, L. Schäfer, Suhrkamp, s. 84-127.

/// Fleck L. 1983b. Erfahrung und Tatsache: Gesammelte Aufsätze, red. Schnelle, L. Schäfer, Suhrkamp. 
/// Fleck L. 1983c. Über die wissenschaftliche Beobachtung und die Wahrnebmung im allgemeinen, tłum. B. Wolniewicz, T. Schnelle, [w:] tegoż, Erfahrung und Tatsache: Gesammelte Aufsätre, red. Schnelle, L. Schäfer, Suhrkamp, s. 59-83.

/// Fleck L. 1983d. Wissenschaftstheoretische Probleme, tłum. B. Wolniewicz, T. Schnelle, [w:] tegoż, Erfahrung und Tatsache: Gesammelte Aufsätrze, red. Schnelle, L. Schäfer, Suhrkamp, s. 128-146.

/// Fleck L. 1986a. Powstanie i rozwój faktu naukowego. Wprowadzenie do nauki o stylu myślowym i kolektywie myślowym, tłum. M. Tuszkiewicz, Wydawnictwo Uniwersytetu Marii Curie-Skłodowskiej.

/// Fleck L. 1986b. Problems of the Science of Science, ttum. [prawdopodobnie] T. Schnelle, R.S. Cohen, F. Lachman, [w:] Cognition and Fact: Materials on Ludwik Fleck, red. T. Schnelle, R.S. Cohen, D. Reidel Publishing Company, s. 113-127.

/// Fleck L. 1986c. Scientific Observation and Perception in General, tłum. [prawdopodobnie] T. Schnelle, R.S. Cohen, F. Lachman, [w:] Cognition and Fact: Materials on Ludwik Fleck, red. T. Schnelle, R.S. Cohen, D. Reidel Publishing Company, s. 59-78.

/// Fleck L. 1986d. The Problem of Epistemology, tłum. [prawdopodobnie] T. Schnelle, R.S. Cohen, F. Lachman, [w:] Cognition and Fact: Materials on Ludwik. Fleck, red. T. Schnelle, R.S. Cohen, D. Reidel Publishing Company, s. 79-112.

/// Fleck L. 2006. Psychosocjologia poznania naukowego. „Powstanie i roz̧wój faktu nankowego" oraz inne pisma z filozofii poznania, red. Z. Cackowski, S. Symotiuk, Wydawnictwo Uniwersytetu Marii Curie-Skłodowskiej.

/// Fleck L. 2007. Style myslowe i fak.ty. Artykuty i świadectwa, red. S. Werner, C. Zittel, F. Schmaltz, Wydawnictwo Instytutu Filozofii i Socjologii PAN.

/// Fleck L. 2011. Denkstile und Tatsachen: gesammelte Schriften und Zeugnisse, red. S. Werner, C. Zittel, F. Schmaltz, Suhrkamp.

/// Friedman A.W., Rossman Ch., Sherzer D. 1987. Beckett translating/translating Beckett, Pennsylvania State University Press.

/// Jarnicki P. 2008. Fleck a metafory, [w:] Wrorce postrzegania rzeczywistości w nauce $i$ społeczeństwie, red. B. Płonka-Syroka, DiG, s. 167-208. 
/// Jarnicki P. 2015. Problems with Translations of Ludwik Fleck: the Example of the Concept of „Legitimation”, „Divinatio: Studia Culturologica Series”, t. 41, Autumn-Winter, s. 167-184.

/// Jarnicki P. 2016. On the Shoulders of Ludwik Fleck? On the Bilingual Philosophical Legacy of Ludwik. Fleck and its Polish, German and English Translations, „The Translator". http://www.tandfonline.com/doi/abs/10.1080/1355650 9.2015.1126881; dostęp: 08.10.2016 .

/// Kuhn T.S. 1979. Foreword, [w:] L. Fleck, Genesis and Development of a Scientific Fact, red. T.J. Trenn, R.K. Merton, R.K., tłum. F. Bradley, T.J. Trenn, The University of Chicago Press, s. VII.

/// Kuhn T.S. 2011. Stowo wstepne, tłum. P. Jarnicki, M. Zuber, „Studia Philosophica Wratislaviensia”, nr 2, s. 81-85.

/// Leszczyńska K. 2007. Ludwik. Fleck - zapomniany filozof, „Midrasz”, nr 1, s. $36-47$.

/// Sady W. 2012. Ludwik. Fleck, [w:] The Stanford Encyclopedia of Philosophy, red. E.N. Zalta. http://plato.stanford.edu/entries/fleck/, dostęp: 08.10.2016.

/// Schickore J. 2014. Scientific Discovery, [w:] The Stanford Encyclopedia of Philosophy, red. E.N. Zalta. http://plato.stanford.edu/entries/scientific-discovery/; dostęp: 30.11.2015.

\section{/// Abstrakt}

Artykuł przedstawia problemy językowe, które wynikają z tłumaczeń dwujęzycznej filozoficznej spuścizny Ludwika Flecka (1896-1961). Autor szczegółowo analizuje przypadek ,legitymacji” w odniesieniu do sposobu, w jaki Fleck używał tego pojęcia w swoich oryginalnych polskich i niemieckich tekstach. Zarówno polscy, jak i angielscy tłumacze nie rozpoznali polskiego „legitymować” oraz niemieckiego „legitimieren” i ich wyrażeń pokrewnych jako swoich ekwiwalentów, dlatego jedno z ważniejszych Fleckowskich pojęć może być źle rozumiane.

Słowa kluczowe:

Ludwik Fleck, dwujęzyczna spuścizna, legitymacja, kontekst uzasadnienia 


\section{/// Abstract}

This paper introduces the linguistic problems resulting from translations of the bilingual philosophical legacy of Ludwik Fleck (1896-1961). The case of "legitimation" is analysed in detail in accordance with the way it was used by Fleck in his original Polish and German texts. Neither Polish nor English translators recognised Polish "legitymować" and its derivatives nor German "legitimieren" and its derivatives as equivalent expressions; hence, one of the most important Fleckian concepts may be misunderstood.

Key words:

Ludwik Fleck, bilingual legacy, legitimation, context of justification 